\title{
PENGUATAN MANAJEMEN PENINGKATAN MUTU BERBASIS SEKOLAH (MPMBS)
}

\author{
BAHARUDDIN \\ Fakultas Tarbiyah dan Keguruan \\ Universitas Islam Negeri Alauddin Makassar
}

\begin{abstract}
:
School management with a strategic plan is considered successful if it is able to raise the quality of processes and products of quality education and learning. Therefore the ability of school principals, school personnel and others to implement a strategy within a school is very important, in relation to the ability of the principal as a leader and teachers as professionals responsible for the progress of learners. The principal is required to have the ability to manage and formulate the development of school vision, mission and objectives and to identify school programs that can support the learning process including curriculum, human resources, facilities and infrastructure, provision of guidance for educators, and dynamic active participation of parents, including institutions / institutions that have concern for education.
\end{abstract}

Keywords: Management, Strategy, Quality and Education

\section{LATAR BELAKANG}

erkembangan ilmu pengetahuan dan teknologi telah membawa perubahan dihampir semua aspek kehidupan manusia dimana berbagai permasalahan hanya dapat dipecahkan kecuali dengan upaya penguasaan dan peningkatan ilmu pengetahuan dan teknologi. Selain manfaat bagi kehidupan manusia di satu sisi perubahan tersebut juga telah membawa manusia ke dalam era persaingan global yang semakin ketat. Agar mampu berperan dalam persaingan global, maka sebagai bangsa kita perlu terus mengembangkan dan meningkatkan kualitas sumber daya manusianya. Oleh karena itu, peningkatan kualitas sumber daya manusia merupakan kenyataan yang harus dilakukan secara terencana, terarah, intensif, efektif dan efisien dalam proses pembangunan, kalau tidak ingin bangsa ini kalah bersaing dalam menjalani era globalisasi tersebut.

Salah satu strategi untuk meningkatkan kualitas pendidikan adalah penerapan manajemen strategi. Alasan yang mendasar adalah bahwa konsep manajemen strategi menawarkan kepada sekolah untuk menyediakan pendidikan yang lebih baik dan lebih memadai bagi peserta didik. Konsep ini menekankan kepada upaya sekolah dalam mengidentifikasi apa yang ingin mereka capai, dan bagaimana seharusnya mereka mencapai hasil yang bernilai guna dalam tatanan ruang lingkup pendidikan sehingga sekolah dapat memahami kekuatan bersaing dan mengembangkan keunggulan kompetitif berkelanjutan secara sistematis dan konsisten. 
Penyusunan manajemen strategi yang terfokus pada peningkatan mutu pendidikan, itu sangat terkait dengan kinerja seorang guru. Guru merupakan bagian dari sistem pendidikan yang menempati posisi yang strategis dalam pengelolaan dan pengembangan pembelajaran. Maka dari itu, guru dituntut agar dapat menjadi tombak pembentukan sumber daya manusia yang handal. Oleh karena itu, guru harus memiliki kecakapan profesional terkhusus kepada penerapan strategi pembelajaran yang efektif dan efisien dalam meningkatkan kualitas pendidikan peserta didik.

Dalam mewujudkan suata pendidikan yang bermutu tentunya dibutuhkan suatu manajemen yang baik. Manajemen yang baik itu tentunya mengacu pada fungsi-fungsi manajemen itu sendiri, dimana fungsi-fungsi yang dimaksudkan tidak lain adalah perencanaan (planning), pengorganisasian (organizing), pengawasan (controling), serta evaluasi (evaluation), maka kegiatan belajar mengajar dapat berjalan secara terencana, sistematis, berkesinambungan yang sesuai dengan standar mutu pendidikan.

\section{KAIIAN PUSTAKA}

\section{Manajemen Strategik}

Secara harfiah manajemen strategik terbangun dari dua kata yaitu manajemen dan strategik. Kata manajemen berasal dari kata to manage yang artinya mengatur. Penagturan dilakukan melalui proses dan diatur berdasarkan urutan dari fungsi-fungsi manajemen itu (Hasibuan, 2009:1). Sehingga manajemen diartikan sebagai proses pemahaman sumber daya secara efektif untuk mencapai sasaran yang telah ditentukan (Salim dan Salim, 1991:92). Manajemen merupakan kemampuan dan keterampilan khusus melakukan suatu kegiatan, baik bersama orang lain atau melalui orang lain dalam mencapai tujuan organisasi (Badudu, 2003:216).

Strategi merupakan instrumen manajemen yang ampuh dan tidak dapat dihindari termasuk dalam manajemen sekolah. Strategi sekolah menjelaskan metode dan pendekatan yang digunakan untuk mencapai tujuan strategiknya. Langkah ini dalam proses manajemen strategik sekolah mencakup identifikasi pilihan - pilihan strategik yang mungkin dapat dilakukan untuk mencapai tujuan sekolah, evaluasi alternatif-alternatif strategik dengan menggunakan kriteria yang pasti dan pemilihan sebuah alternatif atau kelompok yang mungkin menjadi strategi sekolah (Sagala, 2001:137).

Ansof berpendapat bahwa Manajemen Strategik adalah suatu pendekatan yang sistematis bagi suatu tanggung jawab manajemen, mengondisikan organisasi ke posisi yang dipastikan mencapai tujuan dengan cara yang akan meyakinkan keberhasilan yang berkelanjutan dan membuat organisasi (sekolah) menjamin atau mengamankan format yang, mengejutkan. Pendekatan yang sistematis untuk melakukan perubahan menjadi hal penting dalam manajemen strategis dan 
melalui pendekatan manajemen strategik harus dipastikan bahwa tujuan akan dicapai. Oleh karena itu para pemimpin sekolah menggunakan pendekatan yang sistematis dalam menyusun strategi program sekolah (Sagala, 2001:129).

Defenisi lain tentang manajemen strategik adalah serangkaian tindakan dan keputusan manajerial yang menentukan kinerja perusahaan dan jangka panjang (Haunger dan Wheelen, 2003:4).

Dari pernyataan di atas, manajemen strategik itu merupakan suatu proses perencanaan yang disusun dan ditentukan oleh seorang pimpinan, yang jika dikaitkan dengan pendidikan berarti yang berwewenang dalam hal tersebut adalah kepala sekolah yang dibantu oleh tenaga pendidik, tanaga kependidikan dan, masyarakat sehingga apa yang direncanakan dapat Sdicapai secara efektif dan efesien.

1. Dimensi-Dimensi Manajemen Strategik

a. Dimensi Waktu Dan Masa Depan

Manajemen Strategik dalam mempertahankan dan mengembangkan eksistensi suatu organisasi berpandangan jauh ke masa depan, dan berperilaku proaktif dan antisipasif terhdap kondisi masa depan yang diprediksi akan dihadapi.

b. Dimensi Internal Dan Eksternal

Dimensi Internal adalah kondisi organisasi pada saat sekarang, berupa kekuatan, kelemahan, peluang, dan hambatan, yang harus diketahui secara tepat untuk merumuskan suatu perencanaan secara jengka panjang. Sedangkan Eksternal pada dasarnya merupakan analisis terhadap lingkungan sekitarnya.

c. Dimensi Pendayagunaan Sumber-Sumber

Manajemen strategik sebagai kegiatan manajemen tidak dapat melepaskan diri dari kemampuan mendayagunakan berbagai sumber daya yang dimilki, agar dapat mencapai suatu tujuan yang diinginkan.

d. Dimensi Keikutsertaan Manajemen Puncak

Rencana harus mampu mengakomodasi seluruh aspek kehidupn organisasi yang berpengaruh pada eksistensinya di masa depan merupakan wewenang dan tanggung jawab manajemen puncak.

e. Dimensi Multi Bidang

Dimensi multi bidang ini berhubungan dengan kewenangan dan tanggung jawab serta ruang lingkup wilayah kerja organisasi.

Sebuah sekolah harus menjadi lembaga yang inovatif, mengalami metamorfosis menuju pembaharuan secara terus menerus. Sekolah hanya akan menjadi lembaga pendidikan yang inovatif jika dipimpin oleh kepala sekolah yang 
inovatif pula. keberhasilan sekolah dalam mengembangkan misinya sangat ditentukan oleh keberhasilan kepala sekolahnya (Danim, 2006:46).

\section{Implementasi Manajemen Strategik}

Schendel dan Hofer mengemukakan bahwa imlpementasi dapat di capai melalui alat administrasi yang dapat dikelompokkan ke dalam tiga kategori yaitu :

a. Struktur yaitu siapa yang bertanggung jawab terhadap apa, kepala sekolah bertanggung jawab kepada siapa.

b. Proses yaitu bagaimana tugas dan tanggung jawab itu dikerjakan masing masiang personal.

c. Tingkah laku yaitu perilaku yang menggambarkan motivasi, semangat kerja, penghargaan, disiplin, etika dan seterusnya.

Berdasarakan implementasi manajemen strategik, konsep tentang manajemen strategis banyak ditujukan pada usaha bisnis dan perusahaan, tetapi konsep tersebut dapat juga dilakukan dan diterapkan pada usaha non bisnis atau non profit bahkan di organisasi pemerintahan dan pendidikan. Sebagai sebuah proses, manajemen strategik menjadikan informasi masa lalu, masa sekarang dan masa yang akan datang. Dari aktivitas dan lingkungan organisasi yang berjalan melalui tahapan-tahapan yang saling berkaitan dan berhubungan antara satu dengan yang lainnya kearah pencapaian suatu tujuan (Haunger dan Wheelen, 2003:9).

Dari uraian di atas, maka implementasi manajemen strategik merupakan suatu konsep pengembangan strategik yang dapat membantu dalam meningkatkan kualitas pendidikan di sekolah.

\section{Mutu Pendidikan}

Secara umum, Mutu adalah gambaran dan karakteristik menyeluruh dari barang atau jasa yang menunjukkan kemampuannya dalam memuaskan kebutuhan yang diharapkan atau yang tersirat. Dalam konteks pendidikan, pengertian mutu mencakup input, proses, dan output pendidikan (Rokhim, http://www.rokhim.net/2013/04 Diakses Pada Tanggal 22 oktober 2013).

Input pendidikan adalah segala sesuatu yang harus tersedia karena dibutuhkan untuk berlangsungnya suatu proses. Input sumber daya manusia dan sumber daya lainnya meliputi kepala sekolah, guru termasuk guru BK, staf, peserta didik, dan sumberdaya lainnya seperti peralatan/bahan, perlengkapan, uang, dll. Sedangkan input untuk perangkat lunak meliputi struktur organisasi sekolah, peraturan perundang-undangan, deskripsi tugas, rencana, program, dsb. Oleh karena itu, tinggi rendahnya mutu input dapat diukur dari tingkat kesiapan input.Makin tinggi tingkat kesiapan input, makin tinggi pula mutu input tersebut.

Proses dikatakan bermutu tinggi apabila pengkoordinasian dan penyerasian serta pemaduan input sekolah (guru, peserta didik, kurikulum, uang, peralatan, dsb) dilakukan secara harmonis, sehingga mampu menciptakan situasi 
pembelajaran yang menyenangkan (enjoyable learning), mampu memberikan motivasi dan minat belaja peserta didik.).

Output pendidikan adalah merupakan kinerja sekolah. Kinerja sekolah adalah prestasi sekolah yang dihasilkan dari proses/perilaku sekolah. Kinerja sekolah dapat diukur dari kualitasnya (menunjukkan kepada suatu ukuran penilaian atau penghargaan), produktivitasnya (perbandingan terbaik antara hasil yang diperoleh output dengan jumlah sumber yang dipergunakan input).

a. Strategi Dalam Peningkatan Mutu

Seluruh manajemen komponen pendidikan harus senantiasa berorientasi pada pencapaian mutu. Semua program dan kegiatan pendidikan serta pembelajaran dilembaga pendidikan pada hakekatnya harus bisa diarahkan pada pencapaian mutu. Walau hingga sekarang ini, persoalan mutu masih menjadi pembahasan ditataran idealisme, belum manjadi realitas dalam lembaga pendidikan, maka perlu dikerahkan semua pikiran, tenaga, strategi untuk bisa mewujudkan mutu tersebut dalam lembaga pendidikan (Qomar, 2007:204).

Penerapan strategi dalam bidang Pendidikan adalah sebagai berikut:

a. Strategi Agresif

Strategi ini dilakukan dengan membuat program-program dan mengatur langkah-langkah atau tindakan mendobrak penghalang, rintangan, atau ancaman untuk mencapai keunggulan/prestasi yang diterapkan.

b. Strategi Konserpatif

Strategi ini dilakukan untuk membuat program-program dan mengatur langkahlangkah atau tindakan dengan cara yang sangat berhati-hati disesuaikan dengan kebiasaan yang berlaku.

c. Strategi Diferennsif

Strategi ini dilakukan dengan membuat program-program dan mengatur langkah-langkah atau tindakan untuk mempertahankan kondisi keunggulan atau prestasi yang sudah dicapai.

d. Strategi Kompetitif

Strategi ini dilakukan untuk membuat program-program dan mengatur langkahlangkah atau tindakan untuk mewujudkan keunggulan yang melebihi organisasi yang sama posisi dan jenjangnya sebagai aparatur pemerintah.

e. Strategi Inovatif

Strategi ini dilakukan dengan membuat program-program, proyek dan mengatur langkah-langkah atau tindakan agar organisasi selalu tampil sebagai pelopor pembaharuan dalam bidang tugas pokok masing-masing, sebagai keunggulan atau prestasi.

f. Strategi Diversifikasi

Strategi ini dilakukan dengan membuat program-program, proyek dan mengatur langkah-langkah atau tindakan berbeda dari strartegi yang 
dipergunakan organisasi profit lainnya di bidang pemerintahan dalam memberikan pelayanan umum dan melaksanakan pembangunan.

g. Strategi Preventif

Strategi ini dilakukan dengan membuat program-program, proyek dan mengatur langkah-langkah atau tindakan untuk mengoreksi dan memperbaiki kekeliruan, baik yang dilakukan oleh organisasi sendiri maupun diperintahkan organisasi atasan (Nawawi, 2005:177).

Mutu pendidikan yang dimaksudkan adalah kemampuan lembaga pendidikan dalam mendayagunakan sumber-sumber pendidikan untuk meningkatkan kemampuan belajar seoptimal mungkin (Qomar, 2007:204).

Sehingga Manajemen sekolah dengan rancangan yang strategik dipandang berhasil jika mampu mengangkat derajat mutu proses dan produk pendidikan dan pembelajaran. Dalam pengertian umum, mutu mengandung makna derajat keunggulan suatu produk atau hasil kerja, baik berupa barang maupun jasa. Barang dan jasa pendidikan itu bermakna dapat dilihat dan tidak dapat dilihat, tetapi dapat dirasakan (Danim, 2006:46).

Peningkatan mutu pendidikan di sekolah perlu didukung oleh kemampuan manajerial para kepala sekolah. Sekolah perlu berkembang dari tahun ke tahun. karena itu hubungan baik antar guru perlu diciptakan agar terjalin iklim dan suasana kerja yang kondusif dan menyenangkan. Demikian halnya dengan penataan lingkungan fisik dan manajemen sekolah perlu dibina agar sekolah menjadi lingkungan pendidikan yang dapat menumbuhkan kreativitas, disiplin dan semangat kerja peserta didik. Dalam kerangka inilah dirasakan perlunya imlpementasi MBS.

Strategi manajemen sekolah menggunakan model MBS dapat memperkuat strategi penyusunan rencana penyelenggaraan program sekolah, pengorganisasian tugas dan tanggung jawab setiap personal sekolah dengan memperkuat alokasi anggaran dan penyediaan fasilitas belajar, pemberdayaan personal dan memadukan fungsi organisasi dengan keputusan strategis, strategi pengetahuan disusun secara sistematis sesuai dengan kecakapan menyesuaikan masalah kebutuhan sekolah, sedangkan strategi informasi memperkuat keterampilan untuk memprebaiki berbagai kegiatan staf dan kemampuan organisasi mengembangkan manajemen berbasis sekolah (Sagala, 2001:169).

Untuk mengimplementasikan manajemen berbasis sekolah secara efektif dan afesien, kepala sekolah perlu memiliki kepemiminan, perencanaan, pandangan yang luas tentang sekolah dan pendidikan. Di samping itu kepala sekolah membina dan memberikan saran-saran positif kepada guru. Dan kepala sekolah juga harus melakukan tukar pikiran, sumbang saran dan study banding antar sekolah untuk menyerap kiat-kiat kepemimpinan dari kepala sekolah yang lain.

Penerapan model MBS tersebut bertujuan untuk: 
a. Meningkatakan mutu pendidikan melalui kemandirian dan inisiatif sekolah dalam mengelola dan memberdayakan sumber daya dan potensi yang tersedia.

b. Meningkatkan kepedulian warga sekolah dalam menyelenggarakan pendidikan melalui pengambilan keputusan bersama.

c. Meningkatkan tanggung jawab sekolah kepada orang tua, sekolah, dan pemerintah tentang mutu sekolah.

d. Menigkatkan kompetisi yang sehat antar sekolah untuk pencapaian mutu pendidikan yang diharapakan (Satori, 2001:5).

Dengan demikian dapat ditegaskan bahwa strategi manajemen model MBS memiliki potensi besar dalam menciptakan kepala sekolah yang visioner dan entrepreneurship, guru dan tenaga kependidikan sebagai pengelola sistem pendidikan secara profesional.

Memenuhi harapan mutu pendidikan yang tinggi tentu diperlukan desentralisasi terhadap fungsi-fungsi manajemen di sekolah untuk mengoptimalkan kebijakan pada tingkat manajemen sekolah dalam melakasanakan programnya. Desentralisasi fungsi-fungsi administrasi manajemen ini memberi kewenangan kepada kepala sekolah bersama seluruh personal sekolah untuk menentukan visi dan misi, menyusun perencanaan sekolah, membagi tugas bagi seluruh personal, memimpin penyelenggaraan program sekolah, melakukan pengawasan dan perbaikan sesuai dengan keperluan. Peningkatan mutu pendidikan ini merupakan usaha yang harus dilaksanakan oleh semua tenaga pendidik untuk mengupayakan peserta didik menjadi manusia yang diharapkan dan memiliki kemampuan di bidang ilmu pengetahuan yang luas. Sehingga konsep utama dalam menuju perbaikan secara kontinu adalah tentunya tidak lepas juga dari TQM ( Toatal Quality Manajemen). Dalam konsep TQM dapat dikatan bahwa pandangn modern tentang proses belajar tampaknya memberikan piranti kepad pengajar dan untuk bekerja sama guna dalam mengoptimalisasikan proses belajar mengajar (Hardjosoedomo, 1996:133).

Oleh karena itu, di dalam peningkatan mutu pendidikan diperlukan kerja sama dari berbagai pihak demi mengoptimalkan suatu kebijakan yang ada dalam suatu sekolah, sebab pendidikan akan meningkat dengan adanya kerjasama.

Implementasi manajemen strategik adalah adalah pengelolaan sumber daya di sekolah dalam hal ini input pendidkan. Input pendidikan ini mencakup tenaga pandidik, sarana dan prasarana, tenaga kependidikan lainnya, peserta didiknya ataupun sampai kepada perngkat-perangkat yang dapat menunjang proses pembalajaran dan proses pencapaian suatu peningkatan mutu pendidikan. diharapkan dapat menghasilakan suatu output yang dapat menghasilkan prestasi yang baik, namun dalam mengukur suatu prestasi seorang peserta didik, maka dibutuhkannya sebuah tolak ukur yang dapat membantu pendidik dalam mengetahui batas penegtahuan . Namun pada hakekatnya tolak ukur dapat dilihat 
dari adanya suatu standar kelulusan yang telah ditentukan dari pihak pemerintah pusat.

Sehingga dalam implementasi manajemen strategik diharapkan dapat meningkatkan suatu mutu pendidikan pada peserta didik dalam berbagai aspek seperti:

Implementasi manajemen strategik merupakan upaya dalam peningkatan mutu pendidikan di sekolah, dimana bertujuan untuk mentransformasi tujuan strategik ke dalam aksi yaitu penyelenggaraan program sekolah. Karena betapapun hebatnya suatu strategi jika tidak diimplementasikan tentu saja strategi tersebut tidak akan bermakna bagi peningkatan suatu mutu pendidikan. Oleh karena itu kemampuan kepala sekolah dan personil sekolah lainnya dalam mengimplementasikan suatu strategi dalam suatu sekolah merupakan hal yang sangat penting dalam kaitannya kemampuan kepala sekolah sebagai seorang pemimpin dan guru sebagai tenaga profesional yang bertanggung jawab terhadap kemajuan peserta didik. Begitu pula hal dengan tenaga kependidikan lainnya dalam hal ini peran tata usaha dalam meningkatkan pendidikan.

1. Penetapan strategi, yang meliputi pengembangan visi, misi dan tujuan jangka panjang dan pengidentifikasian peluang dan ancaman dari luar serta kekuatan dan kelemahan perusahaan atau organisasi, pengembangan alternatifalternatif strategi dan penentuan strategi yang sesuai untuk diadopsi.

2. Penerapan strategik, meliputi penentuan sasaran-sasaran operasional tahunan, kebijakan perusahaan atau organisasi, memotivasi karyawan dan mengalokasikan sumber-sumber daya agar strategi yang telah ditetapkan dan diimplementasikan.

3. Evaluasi atau kontrol strategik, mencakup usaha-usaha untuk memonitor seluruh hasil dari perbuatan dan penerapan strategi, termasuk mengukur kinerja individu dan perusahaan serta mengambil langkah-langkah perbaikan jika diperlukan (Haunger dan Wheelen, 2003:4) yang mencakup beberapa hal yaitu pendekatan, metode, serta model perencanaan yang diterapkan di Sekolah dalam upaya meningkatkan suatu mutu pendidikan.

4. Peningkatan Mutu Pendidikan meliputi input, proses, dan output pendidikan yang saling mempengaruhi. Dalam mengukur suatu mutu pendidikan tentu perlu mengadakan langkah awal sebelum masuk pada proses pembelajaran, perlunya memperhatikan dua aspek yaitu pertama penyeleksian calon baru yang harus melewati beberapa tahap dan tes yang telah ditetapkan dan yang kedua melakukan program-program dalam proses pembalajaran demi mencapai hasil yang diharapkan dari peserta didik yang berpatokan pada suatu standar kelulusan yang telah ditetapkan lebih awal.

5. Dalam mengimplementasikan Manajemen Strategik dalam peningkatan mutu pendidikan peserta didik tentunya ditunjang dari berbagai hal seperti kurikulum, SDM, sarana dan prasarana, penyediaan bimbingan bagi para 
tenaga pendidik, dan kedisiplinan bagi seluruh elemen di sekolah serta penyediaan kegiatan-kegiatan yang dapat meningkatkan kualitas peserta didik.

\section{KESIMPULAN}

1. Penetapan strategi manajemen meliputi pengembangan visi, misi dan tujuan peningkatan mutu pendidikan di sekolah bersama-sama dengan masyarakat untuk merencanakan dan menyusun program jangka panjang atau jangka pendek (tahunan termasuk anggarannnya. Program tersebut memuat sejumlah program aktivitas yang akan dilaksanakan sesuai dengan kebijakan nasional.

2. Melakukan evaluasi diri (self assesment) utnuk menganalisa kekuatan dan kelemahan mengenai sumber daya sekolah, personil sekolah, kinerja dalam mengembangkan dan mencapai target kurikulum dan hasil-hasil yang dicapai berkaitan dengan aspek-aspek intelektual dan keterampilan, maupun aspek lainnya.

3. Dalam meningkatkan mutu pendidkkan sekolah harus mengidentifikasikan kebutuhan sekolah dan merumuskan visi, misi, dan tujuan dalam rangka menyajikan pendidikan yang berkualitas/ bermutu bagi nya sesuai dengan konsep pembangunan pendidikan nasional yang akan dicapai.

\section{DAFTAR PUSTAKA}

Badudu S. Kamus Kata-Kata Serapan Asing dalam Bahasa Indonesia. Jakarta: PT. Kompas Media Nusantara, 2003

Danim Sudarwan. Visi Baru Manajemen Sekolah. Bengkulu: Bumi Aksara, 2006

Departemen Pendidikan Dan Kebudayaan, Kamus Besar Bahasa Indonesia, Cet. III Jakarta: Balai Pustaka, 2003

Harjdosoedrmo, Soewarso. Total Quality Manajemen. Edisi Revisi. Yogyakarta: Andi, 1996

Hasibuan, Malayu S.P. Manajemen. Cet III. Jakarta: Bumi Aksara, 2009

Haunger David J., \& Wheleen Thomas L. Manajemen Strategi. Yogyakarta: Andi, 2003

Peter, Salim dan Salim Yenny. Kamus Besar Bahasa Indonesia Kontemporer. Ed. I. Jakarta: Modren English Press, 1991

Qomar, Mujamil. Manajemen Pendidikan Islam. Jakarta Timur: Eerlangga, 2007

Rokhim, Pengertian Mutu Pendidikan, (http://www.rokhim.net/2013/04 Diakses Pada Tanggal 22 oktober 2013).

Sagala, Syaiful. Manajemen Strategik Dalam Peningkatan Mutu Pendidikan. Cet V. Bandung: CV. Alfabeta, 2001. 